\title{
EMPOWERING WOMEN ENTREPRENEURS THROUGH KREDIT USAHA RAKYAT (KUR) FUNDS IN CENTRAL JAKARTA
}

\author{
R.A. Aryanti Wardaya Puspokusumo, Henny Kurniawati, Maryani \\ Bina Nusantara University, Indonesia \\ rpuspokusumo@binus.edu
}

\begin{abstract}
Micro, Small and Medium Enterprises (MSMEs) are important contributors to economic development. However, increasing the performance of MSMEs faces many obstacles and challenges, especially in the face of competition. Lack of understanding to manage businesses, capital and difficult access to external capital are the main challenges that must be faced by MSME entrepreneurs. MSME entrepreneurs find it difficult to obtain loan capital because they do not have sufficient assets to meet the loan requirements at the bank. To overcome this problem the Government issued a policy in the form of a credit program for MSMEs with guarantees namely People's Business Credit (KUR). KUR is expected to be able to help MSME entrepreneurs to increase business capital, so that business performance can improve. The purpose of this activity is to find out the difficulties faced by women MSME entrepreneurs, increase understanding in managing businesses, and provide understanding to access KUR funds. This activity was carried out in central Jakarta with a total of 150 female MSME owners. The method used is observation, training and filling out the questionnaire. The result of this activity is a report on the activities of the training conducted.
\end{abstract}

Keywords: Women Entrepreneur, SME, Microfinancing, Performance

\section{INTRODUCTION}

Indonesia, a member of the G20 since 2008, has become one of the largest economies in the world and experts see great growth potential in the coming decades. In order to realize this potential, the Government of Indonesia has identified the micro, small and medium business sector (MSME) as the key to promoting growth, job creation, and poverty alleviation. MSMEs contribute $99 \%$ of all businesses, employ $89 \%$ of the private sector workforce, and contribute $57 \%$ to GDP. The number of MSMEs as well as MSME employment that has expanded in recent years is a major driver for poverty reduction and increased income.

The IFC report states that there are sizable market opportunities in the MSME sector in Indonesia. This sector is one of the fastest growing sectors in Indonesia and shows great potential. Nevertheless, this sector has not been well served for quite a long time. In line with Indonesia's transition from an labor-intensive to capitalintensive economy, this sector is ready to develop. A study from IFC found that the potential demand for loans / credit from women entrepreneurs is quite large at US \$ 6 billion.

MSMEs owned by women comprise more than half of all small businesses and around one third of all medium-sized businesses, thus contributing to economic growth and job creation which is about the same size as that of male-owned SMEs. Although the weaknesses of business metrics are often associated with women's SMEs, their performance is not lower than men's SMEs. The foresight in doing business is the same as men's businesses and more female SMEs than male SMEs say that they are very profitable. Compared to male-owned SMEs, women face multiple responsibility constraints, from business, on the one hand, and family and household, on the other. Lack of property ownership, lack of prior business experience, limited mobility and greater dependence on husband and family are some of the factors that hamper the growth and development of women's MSMEs.

The main problem faced by MSMEs is related to capital for business development. Generally, MSME managers have difficulty in getting access to credit for business capital from banking institutions. This is because the banking sector considers MSMEs unfeasible to obtain credit, because the MSME sector is difficult to develop and there are fears of bad credit. (Priminingtyas, 2010). Most MSME sectors managed by women experience greater difficulties. This is because women are also multi-role in managing their businesses, where women in addition to being managers also work as workers. Therefore we need education and skills in managing a business so that it can develop properly. But the reality in the community, many women with low levels of education and do not have enough good skills in running their businesses so that many businesses are down. With a low level of education, it is difficult for women to access credit from banking institutions. Moreover, the requirements requested by the bank for MSMEs to apply for credit are numerous, including the need for collateral. Collateral required by the bank, such as land, house and vehicle ownership certificates (BPKB), is generally in the name of the husband. Women do not have control over available resources, such as land, houses and vehicles. As a result, many MSMEs managed by women are entangled in loan sharks which are so burdensome that their businesses go bankrupt. Although the government has issued a People's Business Credit (KUR) program to help MSMEs, 
which are unsecured soft loans for credit schemes of less than Rp. 5,000,000.00. But in reality the bank always asks for guarantees so that the MSMEs have the motivation in completing their obligations. This has made it difficult for the MSME sector to develop due to limited capital (Priminingtyas, 2010).

The Government of Indonesia and Bank Indonesia offer a number of support services aimed at developing the MSME sector by increasing knowledge and networks and reducing obstacles in accessing finance. However, most programs target the needs of microbusinesses rather than SMEs. In addition, there are no programs that explicitly target women-owned SMEs.

The funding assistance program is generally through three agencies. While the government, which is usually represented by the Ministry of Cooperatives and SMEs or the Ministry of Industry, cooperates with the local government in implementing the program. $\mathrm{BI}$ is free to launch the send program.

\section{MATERIALS AND METHODS}

In solving problems with women entrepreneurs in managing capital loans and problems, the steps taken are: Conducting surveys and observations of female entrepreneurial partners; prepare materials for entrepreneurship training and capital and financial training to get KUR funds; team and resource persons preparation; conducting entrepreneurship training and socializing KUR funds for empowering women entrepreneurs; monitoring and evaluating training results; Scientific publications in journals / proceedings; report on the implementation of the Community Partnership Program

In implementing the Activity Partnership Program Society, the approach used by conducting training in the form of entrepreneurship concepts and KUR socialization to women entrepreneurs in Central Jakarta to overcome funding problems. The training was conducted by inviting Bank X Central Jakarta to provide an understanding of KUR. Submission of material is done through lectures and discussions.

This activity was carried out in two locations different, namely Bina Nusantara University and Karet Tengsin Flat, Bendungan Hilir. Entrepreneurship training activities and KUR were held at the Bina Nusantara University campus on April 29, 2019 at 10:00 - 14:00 with entrepreneurial material and introduction to the KUR concept. While filling out the questionnaire was carried out in the Bendungan Hilir Flats.

\section{RESULTS OF ACTIVITIES}

This activity was carried out twice in different locations, the first carried out at Bina Nusantara University and the second at the Karet Tengsin Flats, Bendungan Hilir.

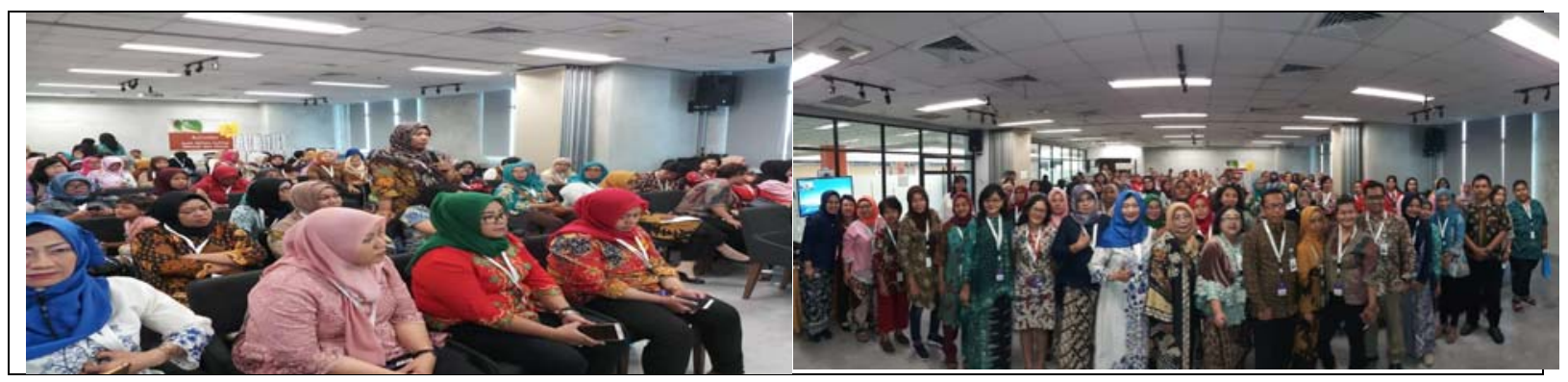

Figure 1. Entrepreneurship Training Session

The first activity (Figure 1) was carried out at the Bina Nusantara University campus on April 29, 2019 at 10:00 - 14:00. The entrepreneurship training session explained about business management. The second session (Figure 2) is an introduction to the KUR concept. The trainees are women entrepreneurs who are domiciled in Central Jakarta (Tanah Abang, Karet Tengsin and Bendungan Hilir). 


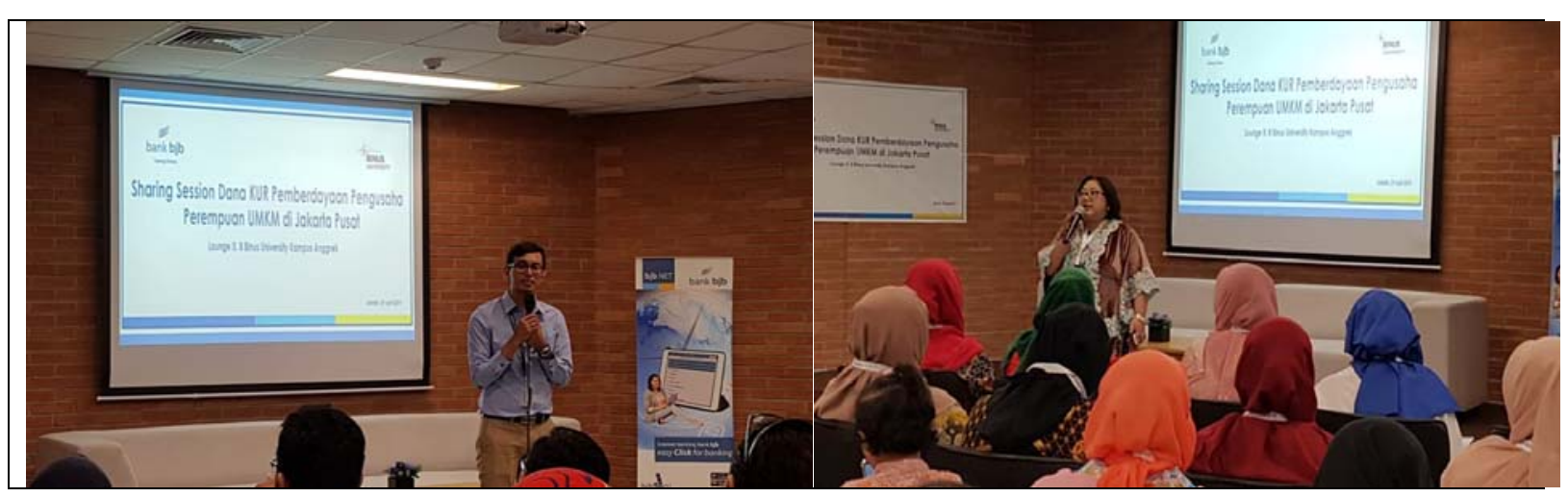

Figure 2. Introduction KUR

The event invited 200 women entrepreneurs, but there were 150 women entrepreneurs. In the training the speakers explained the concepts of entrepreneurship and KUR. The resource person also explained about the opportunities and procedures for obtaining the loan or credit.

The second event was held at Karet Tengsin Flat, Bendungan Hilir. In the event women entrepreneurs filled out questionnaires that explored their understanding and perceptions of KUR funds. At this event 9 female entrepreneurs were identified that had received KUR from Bank X. Based on the answers to the questionnaire, it was found that the training participants had increased their insights and knowledge regarding business management and capital from KUR funds. Not only did women entrepreneurs start to understand that there was an opportunity to get KUR funds, but also to understand the obstacles and problems in selection to get the KUR assistance.

\section{CONCLUSIONS AND RECOMMENDATIONS}

Based on surveys, training and questionnaires distributed to women entrepreneurs in Central Jakarta, the problems faced by women owners of MSMEs can be solved. Providing insight and understanding of business management is explained in entrepreneurship training. For capital problems, women entrepreneurs are given insight and understanding about KUR funds that can be accessed by the community.

By paying attention to the educational background of women entrepreneurs who are participating in the activities, it is necessary to do a learning process and business management assistance accompanied by increased financial insight and literacy so that the opportunity to obtain KUR funds and other funds is greater. In addition, active participation from banks and campus is needed to provide socialization and tips on access to KUR funds.

\section{REFERENCES}

Agung Alit Semara Putra, I Gusti. 2013. Efektivitas Program Bantuan Kredit Usaha

Rakyat (KUR) Terhadap Pendapatan dan Kesempatan Kerja Usaha Mikro Kecil dan Menengah (UMKM) di Kota Denpasar. e-Jurnal Ekonomi Pembangunan (2)10 Oktober 2013. Fakultas Ekonomi dan Bisnis Universitas Udayana.

Athesa, Ade dan Edia Handiman. 2006. Bank dan Lembaga Keuangan Bukan Bank.

Jakarta: PT. Indeks.

Ghozali I. 2006. Aplikasi Analisis Multivariate dengan Program SPSS. Semarang: Badan Penerbit Universitas

Diponegoro.

Gilarso, T. 1998. Ekonomi Indonesia Sebuah Pengantar. Yogyakarta : Kanisius.

E-JURNAL EKONOMI PEMBANGUNAN UNIVERSITAS UDAYANA Vol.4, No.12 Desember 2015 Inayah, Nurul, dkk. 2014. Pengaruh Kredit Modal Kerja Terhadap Pendapatan Bersih

Usaha Kecil dan Menengah (UKM) Sektor Formal. e-Journal Bisma (2)1 Januari 2014. Universitas Pendidikan Ganesha. 
Inessa Love, Lorenzo A. Preve, dan Virginia Sarria-Allende. 2005. Trade Credit and Bank Credit: Evidence from Recent Financial Crises. Journal of International Banking and Monetary: Development Research Group, World Bank (12)1Maret 2005.

Jumhur. 2009. Analisis Permintaan Kredit Modal Kerja Usaha Kecil di Kota Pontianak. Jurnal Bisnis dan Ekonomi (JBE) (16)2 September 2009. Fakultas Ekonomi Universitas Tanjungpura Pontianak.

Maratis Suhartini, Atik, Ropika Yuta . 2014. Keterkaitan Lembaga Keuangan Mikro, (LKM), Usaha Mikro dan Kecil (UMK) Serta Kemiskinan di Indonesia. Jurnal Ekonomi Kuantitatif Terapan (7)2 Agustus 2014. Fakultas Ekonomi Universitas Udayana.

Mulyono, 2006. Kajian Dampak Program Perkreditan Dan Perkuatan Permodalan Usaha Kecil Menengah Terhadap Perekonomian Daerah. Jurnal Pengkajian Koperasi dan UKM (2)1 2006 Hal 23-21.

Munizu, Muhran. 2010. Pengaruh Faktor-Faktor Eksternal dan Internal Terhadap Kinerja Usaha Mikro dan Kecil (UMK) di Sulawesi Selatan. Jurnal Manajemen dan Kewirausahaan (12)1 Maret 2010. Fakultas Ekonomi Universitas Hasanuddin.

Peraturan Menteri Keuangan. 2008. Fasilitas Penjaminan Kredit Usaha Rakyat. Jakarta.

Pradipta Widyaresti, Enggar. 2012. Analisis Peran BRI Unit Ketandan Dalam Pemberian Kredit Usaha Rakyat Bagi Pengusaha Mikro dan Kecil Di Kecamatan Ngawen Kabupaten Klaten. Journal of Economics (1)1 Maret 2012, Hal. 1-11. Fakultas Ekonomi dan Bisnis Universitas Diponegoro.

Siamat, Dahlan. 2004. Manajemen Lembaga Keuangan. Jakarta : Lembaga Penerbit Fakultas Ekonomi Universitas Indonesia.

Strahan, Philip E, Nicola Cetorelli. 2004. Finance as a Barrier to Entry: BankCompetition and Industry Structure in Local U.S. Markets. Carroll School of Management 